\title{
ANALISIS KENDALA PEMBELAJARAN KATA BANTU BILANGAN BAHASA MANDARIN BESERTA SOLUSINYA
}

\author{
Rosemary Sylvia
}

Chinese Department, Bina Nusantara University, Jl. Kemanggisan Ilir III No. 45,

Kemanggisan/Palmerah, Jakarta Barat 11480, rosemary@ binus.edu

\begin{abstract}
For foreigner, Mandarin language numeral words are very dificult to be mastered. Students of Bina Nusantara University are also having difficulties in learning the Mandarin language numeral words. Hopefully using quiz and questioner able to find the dificultioes faced by the students of Bina Nusantara University in learning Mandarin language numeral words. Also using questioner and interview to find the solustions. The research object is Chinese students of Bina Nusantara University from 2-4 semesters. Result from the data analysis is the student did not master well of the Mandarin language numeral words. The student time study in Bina Nusantara University did not have much effect on the student mastering of the Mandarin language numeral words. What causing the student having difficulties in learning the Mandarin language numeral words are because the numeral words in Mandarin language is too much also the usage is very wide.
\end{abstract}

Keywords: Mandarin language, student, numeral word

\begin{abstract}
ABSTRAK
Bagi pelajar asing, kata bantu bilangan bahasa Mandarin sulit untuk dikuasai. Mahasiswa Universitas Bina Nusantara dalam mempelajari kata bantu bilangan bahasa Mandarin juga mengalami berbagai kesulitan. Diharapkan melalui kuis dan penyebaran kuesioner dapat mencari kesulitan yang dialami mahasiswa Universitas Bina Nusantara dalam mempelajari kata bantu bilangan bahasa Mandarin dan juga melalui kuesioner dan wawancara mencari solusinya. Objek penelitian adalah mahasiswa sastra China tingkat 2-4 Universitas Bina Nusantara. Dari hasil analisis data diketahui penguasaan mahasiswa akan kata bantu bilangan bahasa Mandarin tidak baik. Lama waktu belajar di Universitas Bina Nusantara tidak berdampak pada penguasaan mahasiswa akan kata bantu bilangan bahasa Mandarin. Penyebab mahasiswa mengalami kesulitan dalam mempelajari kata bantu bilangan adalah kata bantu bilangan bahasa Mandarin jumlahnya banyak serta cara penggunaannya lebih luas.
\end{abstract}

Keywords: bahasa Mandarin, mahasiswa, kata bantu bilangan 


\section{PENDAHULUAN}

Bahasa Mandarin adalah bahasa perwakilan negara China. Tidak peduli pada zaman dahulu atau masa sekarang, bahasa Mandarin adalah bahasa yang 90\% dipakai oleh bangsa China, juga merupakan bahasa pemersatu yang dipakai oleh berbagai suku di China. Bahasa Mandarin merupakan salah satu bahasa yang paling banyak digunakan oleh orang di dunia. Berdasarkan artikel dari Harian Satelit 22 Juli.1997, Bahasa Mandarin digunakan oleh 1.123 milyar orang di dunia.

Setelah reformasi di China, perekonomian China terus mengalami perkembangan. Posisi China di dunia internasional semakin lama semakin meningkat. Perkembangan bahasa Mandarin di dunia pun semakin besar. Bahasa Mandarin merupakan salah satu bahasa yang digunakan oleh PBB mulai dari 1945. Dalam pergaulan internasional, bahasa Mandarin mempunyai peran yang penting. Di dunia internasional, lembaga yang meneliti bahasa Mandarin terus berkembang, orang yang belajar dan meneliti bahasa Mandarin semakin bertambah. Banyak warga negara di seluruh dunia belajar Mandarin, termasuk Indonesia. Sekarang ini di Indonesia, bahasa Mandarin sangat diminati. Tidak hanya di Jakarta, di kota besar lainnya sudah banyak sekolah yang menyediakan pelajaran Mandarin.

Selain harus menguasai bahasanya, orang asing yang ingin mempelajari bahasa Mandarin juga harus menguasai karakter/tulisan bahasa Mandarin dan kosakatanya, keistimewaan tata bahasa Mandarin, dan menguasai tata bahasa dasar membuat kalimat. Salah satu keistimewaan bahasa China modern adalah mempunyai kata bantu bilangan yang banyak. Satu kata benda, satu kegiatan semua ada kata bantu bilangan yang pasti, tidak boleh tidak digunakan, juga tidak boleh dipakai sembarangan. Cara penggunaan kata bantu bilangan sangat luas dan juga sulit. Pada saat belajar bahasa Mandarin harus memperhatikan hal tersebut.

Untuk mengetahui kesulitan yang dihadapi mahasiswa Universitas Bina Nusantara dalam mempelajari kata bantu bilangan bahasa Mandarin, diputuskan untuk mengadakan penelitian. Melalui artikel ini diharapkan pembaca dapat lebih mengerti pentingnya pembelajaran kata bantu bilangan bahasa Mandarin, lebih menguasai tata cara penggunaan kata bantu bilangan bahasa Mandarin, mengurangi kesalahan dalam penggunaan kata bantu bilangan bahasa Mandarin, dan juga meningkatkan pengetahuan mahasiswa akan bahasa Mandarin.

\section{Analisis Data}

Pada tanggal 7 April 2008 dilakukan penelitian terhadap mahasiswa tingkat 2 sampai 4 Universitas Bina Nusantara. Penelitian dibagi menjadi dua bagian. Bagian satu adalah tes. Melalui tes, dapat diketahui pengguasaan responden akan kata bantu bilangan bahasa Mandarin. Bagian dua adalah kuesioner. Melalui kuesioner, dapat diketahui kesulitan yang dihadapi mahasiswa dalam mempelajari kata bantu bilangan, penyebab terjadinya kesulitan, dan pandangan mahasiswa tentang cara meningkatkan penguasaan akan kata bantu bilangan bahasa Mandarin.

\section{Tes}

\section{Tujuan Tes}

Tujuan tes adalah untuk mengetahui kata bilangan mana saja yang sering salah dan pengguasaan mahasiswa Universitas Bina Nusantara terhadap kata bantu bilangan bahasa Mandarin. 


\section{Sasaran Penelitian}

Sasaran penelitian dibatasi dengan target minimal yang harus dicapai ialah $70 \%$ dari total mahasiswa. Oleh karena itu, digunakan perhitungan strata dalam mengambil sampel sebagai berikut.

$$
\mathrm{N}=\mathrm{c} / \mathrm{y} \cdot \mathrm{n}
$$

Keterangan:

$$
\begin{aligned}
& \mathrm{N}=\text { Jumlah sampel yang harus diambil } \\
& \mathrm{c}=\text { Target jumlah sampel } \\
& \mathrm{y}=\text { Jumlah populasi tingkat } 2,3,4 \\
& \mathrm{n}=\text { jumlah populasi setiap strata }
\end{aligned}
$$

Total mahasiswa tingkat 2 sampai 4 di Universitas Bina Nusantara sebagai y adalah 270 orang, total mahasiswa tingkat 2 sebagai $\mathrm{n} 1$ adalah 107 orang, total mahasiswa tingkat 3 sebagai $\mathrm{n} 2$ adalah 75 orang, total mahasiswa tingkat 4 sebagai $\mathrm{n} 3$ adalah 88 orang.

Berdasarkan hasil perhitungan, mahasiswa tingkat 2 harus mencapai 75 orang, mahasiswa tingkat 3 harus mencapai 53 orang, mahasiswa tingkat 4 harus mencapai 62 orang.

Penelitian ini mempunyai responden mahasiswa tingkat 2 sebanyak 88 orang, responden mahasiswa tingkat 3 sebanyak 63 orang, responden mahasiswa tingkat 4 sebanyak 66 orang. Responden yang mengikuti penelitian ini lebih besar dari perhitungan yang seharusnya, hal itu menunjukkan bahwa jumlah responden penelitian memenuhi persyaratan.

Sesuai formula oleh Erwan Agus Purwanto dan Dyah Ratih Suliyastuti adalah sebagai berikut.

$$
\mathrm{N}=\mathrm{c} / \mathrm{y} \cdot \mathrm{n}
$$

$$
\begin{array}{ll}
\mathrm{Y} & =270 \\
\mathrm{n} 1 & =107 \text { 人 } \\
\mathrm{n} 2 & =75 \text { 人, } \\
\mathrm{n} 3 & =88 \text { 人。 } \\
\mathrm{N} 1 & =\geqslant 75 \quad \mathrm{~N} 2 \geqslant 53 \quad \mathrm{~N} 3 \geqslant 62 \\
\mathrm{~N} & =88+63+66>75+53+62
\end{array}
$$

\section{Bahan Tes}

Soal tes diambil dari materi mata kuliah tata bahasa Universitas Bina Nusantara, melalui 《Hanyu Jiaocheng Diyi ce》 、 《Hanyu Jiaocheng Di'er ce》.

\section{Cara Tes}

Agar penelitian menjadi lebih terarah, dibuat kuis menjadi dua bagian, bagian pertama adalah pilihan ganda, bagian ke dua adalah soal isian. Setiap bagian terdiri atas 20 soal.

\section{Cara Penilaian}

Berdasarkan perhitungan pembagian nilai yang dipergunakan di Universitas Bina Nusantara dibagi menjadi: 
- Nilai $85-100=\mathrm{A}$ (sangat baik)

- Nilai 75-84 = B (baik)

- Nilai $65-75=\mathrm{C}$ (cukup)

- Nilai 55-64 = D (kurang)

- Nilai di bawah $55=\mathrm{E}$ (sangat kurang)

\section{PEMBAHASAN}

\section{Hasil Kuis}

Tabel 1 Nilai Rata-rata Mahasiswa di Seluruh Tingkat

\begin{tabular}{|c|c|c|c|c|c|c|}
\hline $\begin{array}{l}\text { Bagian } \\
\text { Tingkat } \\
\text { Nilai rata-rata responden seluruh kelas }\end{array}$ & $\begin{array}{c}\text { tingkat } 2 \\
69.68\end{array}$ & $\begin{array}{l}\text { Bagian } 1 \\
\text { tingkat } 3 \\
70.58\end{array}$ & $\begin{array}{c}\text { tingkat } 4 \\
75.80\end{array}$ & $\begin{array}{c}\text { tingkat } 2 \\
66.38\end{array}$ & $\begin{array}{c}\text { Bagian } 2 \\
\text { tingkat } 3 \\
61.88\end{array}$ & $\begin{array}{c}\text { tingkat } 4 \\
60.54\end{array}$ \\
\hline Nilai rata-rata responden seluruh tingkat & & 72. 02 & & & 62.93 & \\
\hline
\end{tabular}

Dari tabel tersebut diketahui nilai rata-rata bagian pertama yang diperoleh mahasiswa tingkat dua adalah 69.68 ( C ) dan nilai bagian dua adalah 66.38 ( C ). Nilai rata-rata bagian pertama yang diperoleh mahasiswa tingkat 3 adalah 70.58 ( C ) dan nilai bagian 2 adalah 61.88 ( D ). Nilai rata-rata bagian pertama yang diperoleh mahasiswa tingkat 4 adalah 75.80 ( B ) dan bagian kedua adalah 60.54 ( D ).

Nilai rata-rata bagian pertama dari seluruh tingkat adalah 72.02 ( C ) dan bagian kedua adalah 62.93 ( D ). Berdasarkan cara penilaian Universitas Bina Nusantara, nilai yang diperoleh responden di seluruh tingkat pada bagian pertama lulus, bagian kedua tidak lulus. Hal itu berarti penguasaan kata bantu bilangan mahasiswa di setiap tingkat tidak baik. Meskipun pada bagian pertama nilai yang diperoleh responden mahasiswa tingkat keempat lebih tinggi dibandingkan nilai mahasiswa tingkat kedua dan tiga tetapi pada bagian kedua nilai yang diperoleh mahasiswa tingkat keempat lebih rendah dibandingkan nilai yang diperoleh mahasiswa tingkat kedua dan tiga.

Hal tersebut menunjukkan lama waktu belajar di Universitas Bina Nusantara tidak mempunyai dampak telalu besar pada penguasaan mahasiwa terhadap kata bantu bilangan Mandarin. Meskipun waktu belajar mahasiswa tingkat keempat lebih lama tetapi nilai yang diperoleh tidak lebih tinggi. Peneliti berpendapat bahwa penyebabnya adalah mahasiswa tingkat keempat mulai dari semester tujuh sudah tidak ada pelajaran tata bahasa Mandarin. Oleh karena itu, mahasiswa mulai melupakan tata bahasa Mandarin. Nilai bagian pertama yang diperoleh seluruh mahasiswa di setiap tingkatnya lebih tinggi dibanding nilai bagian kedua. Peneliti berpendapat penyebabnya adalah bagian pertama berupa soal pilihan ganda maka tersedia pilihan jawaban di dalam kuesioner dan responden dapat langsung memilih dari jawaban yang disediakan sedangkan bagian kedua adalah soal mengisi, di dalam kuesioner tidak terdapat pilihan jawaban. Hal itu menyebabkan reponden tidak dapat menjawab soal bagian kedua dan beberapa responden tidak dapat menjawab karena tidak mengerti makna soal yang diberikan. 
Tabel 2 Persentase Kesalahan Seluruh Responden di Seluruh Tingkat pada Soal Bagian Satu

\begin{tabular}{lccccc}
\hline & Tingkat 2 & Tingkat 3 & Tingkat 4 & Total & Persentase \\
\hline soal 1 & 31 & 17 & 8 & 56 & $25.81 \%$ \\
soal 2 & 34 & 38 & 29 & 101 & $46.54 \%$ \\
soal 3 & 30 & 18 & 16 & 64 & $29.49 \%$ \\
soal 4 & 1 & 1 & 2 & 4 & $1.84 \%$ \\
soal 5 & 29 & 26 & 7 & 62 & $28.57 \%$ \\
soal 6 & 22 & 10 & 9 & 41 & $18.89 \%$ \\
soal 7 & 5 & 1 & 4 & 10 & $4.61 \%$ \\
soal 8 & 3 & 3 & 2 & 8 & $3.69 \%$ \\
soal 9 & 60 & 42 & 51 & 153 & $70.51 \%$ \\
soal 10 & 11 & 2 & 6 & 19 & $8.76 \%$ \\
soal 11 & 31 & 5 & 11 & 47 & $21.66 \%$ \\
soal 12 & 11 & 4 & 6 & 21 & $9.68 \%$ \\
soal 13 & 56 & 33 & 29 & 118 & $54.38 \%$ \\
soal 14 & 31 & 14 & 12 & 57 & $26.27 \%$ \\
soal 15 & 37 & 29 & 29 & 95 & $43.78 \%$ \\
soal 16 & 43 & 42 & 27 & 112 & $51.61 \%$ \\
soal 17 & 2 & 1 & 8 & 11 & $5.07 \%$ \\
soal 18 & 54 & 38 & 33 & 125 & $57.60 \%$ \\
soal 19 & 31 & 35 & 15 & 81 & $37.33 \%$ \\
soal 20 & 21 & 9 & 13 & 43 & $19.82 \%$ \\
\hline Dalam satuan & $0 r a n g$ & & & &
\end{tabular}

*Dalam satuan orang

Dari Tabel 2 diketahui mahasiswa di setiap tingkat tidak dapat menguasai dengan baik soal nomor 9,13,16,18. Persentasi kesalahan pada soal nomor 4,7,8,10,12,17 cenderung lebih rendah, kebanyakan responden dapat menjawab dengan baik.

Berikut adalah analisis lebih lanjut mengenai soal dengan persentasi kesalahan tinggi.

- Soal nomor 9 - ( ) 杯子 (a . 杯 b. 个 c. 本 d. 张)

Jawaban yang benar adalah“个” , kebanyakan responden menjawab “杯”, karena mereka merasa “杯” adalah kata bantu bilangan untuk gelas (杯子), mereka tidak memilih “个” karena mereka merasa penggunaan “个” sangat luas, “本” adalah kata bantu bilangan untuk buku,“张” adalah kata bantu bilangan untuk benda yang berbentuk datar, maka dari itu mereka merasa kata bilangan tersebut bukanlah kata bilangan untuk gelas (杯子).

- Soal nomor 13- ( )手 (a. 张 b. 个 c. 只 d. 对)

Jawaban yang benar adalah“只”, kebanyakan responden menjawab “对”, karena arti “对” dalam bahasa Mandarin adalah pasang, mereka tidak mengetahui dengan jelas dalam tata bahasa Mandarin terdapat banyak kata yang juga mempunyai arti pasang, misalnya: “双”, “对” dan lainlain. Beberapa responden juga memili “个”, karena mereka merasa “个” bisa dipasangkan dengan banyak kata benda.

- Soal nomor 16 刚才刮了一（a.下 b. 场 c. 阵 d. 次）大风 Jawaban yang benar adalah“阵”, kebanyakan responden menjawab “场”, karena mereka pernah belajar “一场大雨”, maka dari itu mereka merasa jawaban untuk soal ini adalah “场”, mereka tidak memilih “阵” karena mereka tidak mengerti dengan jelas cara penggunaan “阵”. 
- Soal nomor 18 他连续演了三 (a. 遍 b. 次 c. 场 $\quad$ d. 番) 京剧

Jawaban yang benar adalah“场”, kebanyakan responden menjawab “遍”, karena mereka merasa “遍”berarti pengulangan dari awal sampai akhir. Mereka tidak memilih“场”karena mereka merasa “场” menyatakan kata keterangan tempat.

Tabel 3 Persentase Kesalahan Seluruh Responden di Seluruh Tingkat pada Soal Bagian Dua

\begin{tabular}{cccccc}
\hline & Tingkat 2 & Tingkat 3 & Tingkat 4 & Total & Persentase \\
\hline soal 1 & 8 & 1 & 5 & 14 & $6.45 \%$ \\
soal 2 & 7 & 1 & 4 & 12 & $5.53 \%$ \\
soal 3 & 25 & 19 & 19 & 63 & $29.03 \%$ \\
soal 4 & 33 & 30 & 22 & 85 & $39.17 \%$ \\
soal 5 & 31 & 35 & 30 & 96 & $44.24 \%$ \\
soal 6 & 59 & 44 & 55 & 158 & $72.81 \%$ \\
soal 7 & 24 & 20 & 60 & 22 & $29.03 \%$ \\
soal 8 & 71 & 52 & 42 & 165 & $76.04 \%$ \\
soal 9 & 20 & 12 & 14 & 46 & $21.20 \%$ \\
soal 10 & 26 & 10 & 13 & 49 & $22.58 \%$ \\
soal 11 & 12 & 8 & 13 & 33 & $15.21 \%$ \\
soal 12 & 19 & 17 & 13 & 49 & $22.58 \%$ \\
soal 13 & 16 & 8 & 16 & 40 & $18.43 \%$ \\
soal 14 & 28 & 31 & 42 & 101 & $46.54 \%$ \\
soal 15 & 11 & 15 & 9 & 35 & $16.13 \%$ \\
soal 16 & 3 & 2 & 9 & 14 & $6.45 \%$ \\
soal 17 & 69 & 42 & 50 & 161 & $74.19 \%$ \\
soal 18 & 54 & 40 & 47 & 141 & $64.98 \%$ \\
soal 19 & 7 & 4 & 3 & 14 & $6.45 \%$ \\
soal 20 & 11 & 7 & 16 & 34 & $15.67 \%$ \\
\hline dalam satuan orang & & & &
\end{tabular}

Dari Tabel 3 diketahui penguasaan seluruh responden di setiap tingkat terhadap soal 6,8,17,18 tidak baik. Kebanyakan responden dapat menjawab dengan baik soal 1,2,16. Berikut adalah analisis lebih lanjut mengenai soal dengan persentase kesalahan tinggi.

- Soal nomor 6

Jawaban yang benar adalah“副”, kebanyakan responden menjawab “双”, karena mereka merasa kata bantu bilangan untuk mata dan kacamata adalah sama, kebanyakan responden tidak memahami hal tersebut. Dalam tata bahasa Mandarin, kata bantu bilangan untuk mata dan kacamata tidak sama karena kata bilangan “副” jarang dibahas di buku tulis maka responden tidak memahami cara penggunaan “副”.

- Soal nomor 8

Jawaban yang benar adalah“架”, kebanyakan responden menjawab “辆” karena yang mereka ketahui “辆” adalah kata bantu bilangan untuk kendaraan. Pesawat terbang dan mobil adalah alat transportasi, dalam tata bahasa Indonesia kata bantu bilangan untuk mobil, pesawat, dan alat transportasi lainnya adalah buah maka dari itu responden mengira tata cara penggunaan kata bantu bilangan bahasa Mandarin pun sama dengan bahasa Indonesia.

- Soal nomor 17 爸爸狠狠打了他一（）

Jawaban yang benar adalah"“顿, kebanyakan responden tidak dapat menjawab karena mereka tidak mengerti soal itu. 
- Soal nomor 18 这个电影我看了好几次了, 也没有完整地看完一（）

Jawaban yang benar adalah“遍”, kebanyakan responden menjawab “次” karena dalam tata bahasa Indonesia“次” dan “遍” menyatakan kali, responden tidak mengerti dengan jelas perbedaan “遍” dan“次”.

Dari Tabel 3 diketahui kesalahan bagian pertama di setiap tingkat lebih tinggi, penyebabnya adalah ada sebagian responden tidak mengerti soal yang diberikan, ada sebagian karena ada beberapa kata bantu bilangan jarang muncul di dalam buku tulis. Total pertanyaan dengan persentase kesalahan tinggi pada bagian pertama dan kedua adalah 9 pertanyaan, dalam 9 pertanyaan itu ada 5 pertanyaan yang berhubungan dengan kata bantu bilangan untuk kata benda dan 4 pertanyaan yang berhubungan dengan kata bantu bilangan untuk kata kerja. Hal itu berarti penguasaan responden terhadap kata bantu bilangan untuk kata kerja lebih baik dibanding kata bantu bilangan untuk kata benda. Meskipun cara penggunaan kata bantu bilangan untuk kata kerja juga sama luasnya dengan kata bantu bilangan untuk kata benda tetapi penguasaan responden akan kata bantu bilangan untuk kata kerja lebih baik. Peneliti merasa penyebabnya adalah perbahasaan kata bantu bilangan untuk kata kerja dalam buku tulis tata bahasa yang digunakan Universitas Bina Nusantara sangat terbatas, hanya menbahas beberapa jenis dari kata bantu bilangan untuk kata kerja yang sederhana dan umum. Kebalikannya mengenai jenis kata bantu bilangan untuk kata benda sangat banyak. Oleh karena itu, responden merasa kata bantu bilangan untuk kata kerja lebih gampang dibanding kata bantu bilangan untuk kata benda.

\section{Hasil Kuesioner}

- Menurut Anda, apakah mempelajari kata bantu bilangan bahasa Mandarin itu sulit?

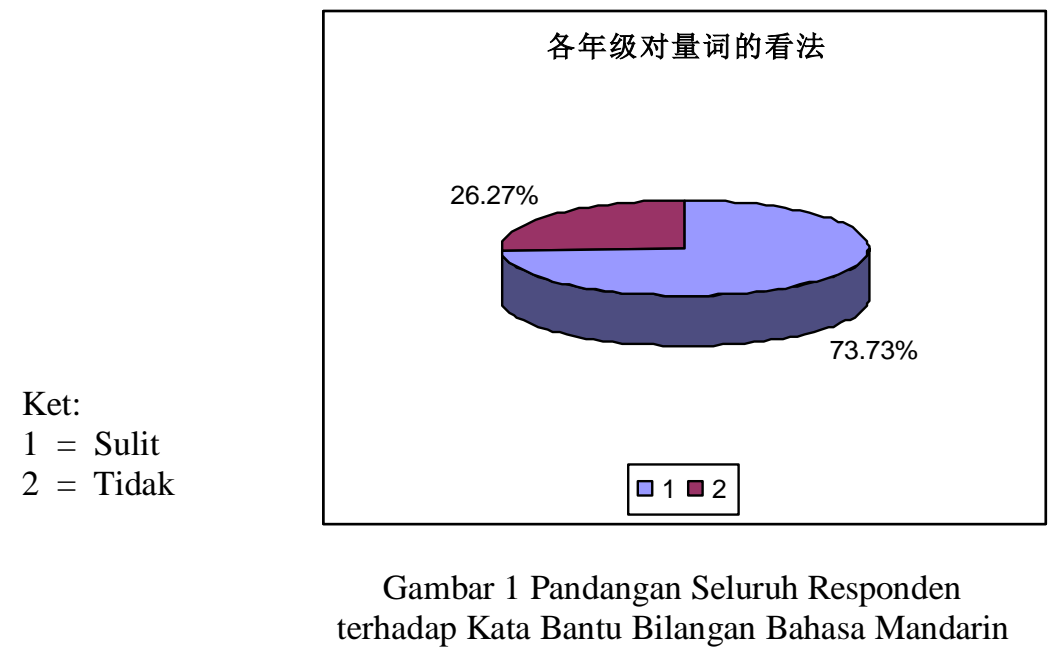

Dari Gambar 1 diketahui dari seluruh tingkat ada $73.73 \%$ responden merasa kata bantu bilangan bahasa Mandarin sangat sulit, $26.27 \%$ responden merasa kata bantu bilangan bahasa Mandarin tidak sulit, dan dari hasil kuis telah diketahui penguasaan kata bantu bilangan bahasa Mandarin tingkat kedua sampai empat tidak baik. Berdasarkan Gambar 1 dapat diketahui kebanyakan responden merasa kata bantu bilangan bahasa Mandarin sulit karena cara penggunaan kata bantu bilangan bahasa Indonesia lebih sederhana apabila dibandingkan dengan cara penggunaan kata benda bilangan bahasa Mandarin yang lebih luas. Hal itu adalah salah satu kesulitan yang dihadapi mahasiswa dalam mempelajari kata bantu bilangan bahasa Mandarin. 
- Pandangan responden terhadap kesulitan mempelajari kata bantu bilangan bahasa Mandarin

Tabel 4 Pandangan Responden

terhadap Kesulitan Mempelajari Kata Bantu Bilangan

\begin{tabular}{lccc}
\hline kesulitan & tingkat 2 & tingkat 3 & tingkat 4 \\
\hline kata bantu bilangan bahasa Mandarin banyak jumlahnya & 49 & 25 & 30 \\
penggunaan kata bantu bilangan bahasa Mandarin lebih & 30 & 20 & 18 \\
luas & 34 & 26 & 23 \\
membutuhkan ketelitian untuk menguasainya & 18 & 7 & 8 \\
jarang dibahas dalam perkuliahan & & \\
\hline
\end{tabular}

*dalam satuan kali orang

Dari Tabel 4 diketahui responden mahasiswa tingkat dua merasa mempelajari kata bantu bilangan bahasa Mandarin sulit karena kata bantu bilangan bahasa Mandarin jumlahnya sangat banyak, responden mahasiswa tingkat tiga merasa mempelajari kata bantu bilangan bahasa Mandarin sulit karena membutuhkan ketelitian agar dapat menguasai, dan responden mahasiswa tingkat empat merasa mempelajari kata bantu bilangan bahasa Mandarin sulit karena kata bantu bilangan bahasa Mandarin jumlahnya sangat banyak. Hal itu menunjukkan kendala terbesar mahasiswa dalam mempelajari kata bantu bilangan bahasa Mandarin adalah kata bantu bilangan bahasa Mandarin jumlahnya sangat banyak.

- Menurut Anda, apakah pelajaran bahasa Mandarin yang diajarkan di Universitas Bina Nusantara membahas dengan jelas tentang penggunaan kata bantu bilangan bahasa Mandarin?

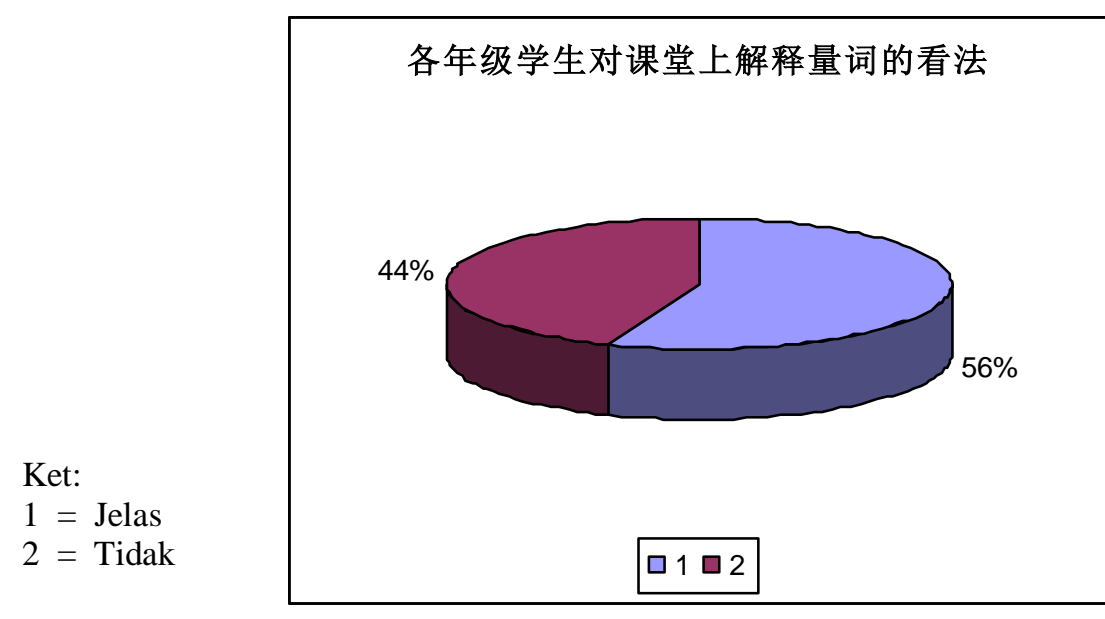

Gambar 2 Pandangan Seluruh Responden terhadap Pembahasan Kata Bantu Bilangan Bahasa Mandarin dalam Pembelajaran di Kelas

Dari Gambar 2 diketahui bahwa mahasiwa di seluruh tingkat ada 56\% mahasiswa merasa pelajaran bahasa Mandarin yang diajarkan di Universitas Bina Nusantara membahas dengan jelas tentang penggunaan kata bilangan bahasa Mandarin, 44\% mahasiswa merasa pelajaran bahasa Mandarin yang diajarkan di Universitas Bina Nusantara tidak membahas dengan jelas tentang penggunaan kata bantu bilangan bahasa Mandarin. Hal itu berarti lebih dari setengah mahasiswa merasa penjelasan tentang kata bantu bilangan di kelas sudah cukup jelas tetapi mendekati setengah mahasiswa merasa tidak jelas. Penulis merasa ada beberapa aspek penyebabnya, yang pertama adalah 
dari aspek materi pengajaran. Melewati penelitian yang lebih jauh dapat diketahui buku tulis yang dipergunakan di Universitas Bina Nusantara sangat sedikit membahas tentang cara penggunaan kata bantu bilangan bahasa Mandarin. Hal yang kedua dari aspek waktu belajar, yaitu waktu belajar di kelas sangat terbatas dan materi pelajaran banyak. Dosen harus menyelesaikan semua mata pelajaran yang ada di dalam buku tulis, waktu untuk menambah materi di luar buku tulis sangat terbatas. Buku tulis yang dipelajari sangat jarang membahas tentang tata cara penggunaan kata bantu bilangan bahasa Mandarin, secara otomatis membuat pembahasaan mengenai kata bantu bilangan bahasa Mandarin menjadi sedikit. Hal tersebut adalah salah satu alasan mengapa mahasiswa merasa materi perkuliahan kurang membahas tentang cara penggunaan kata bantu bilangan bahasa Mandarin. Adapun aspek dalam diri mahasiswa, ada beberapa mahasiswa merasa kata bantu bilangan bahasa Mandarin tidak penting untuk dipelajari, mereka mengira pada saat di kelas cara penggunaan kata bantu bilangan Mandarin sama seperti bahasa Indonesia. Oleh karena itu, mahasiswa tidak memperhatikan pelajaran dengan baik.

- Menurut Anda, bagaimana penguasaan Anda terhadap kata bantu bilangan?

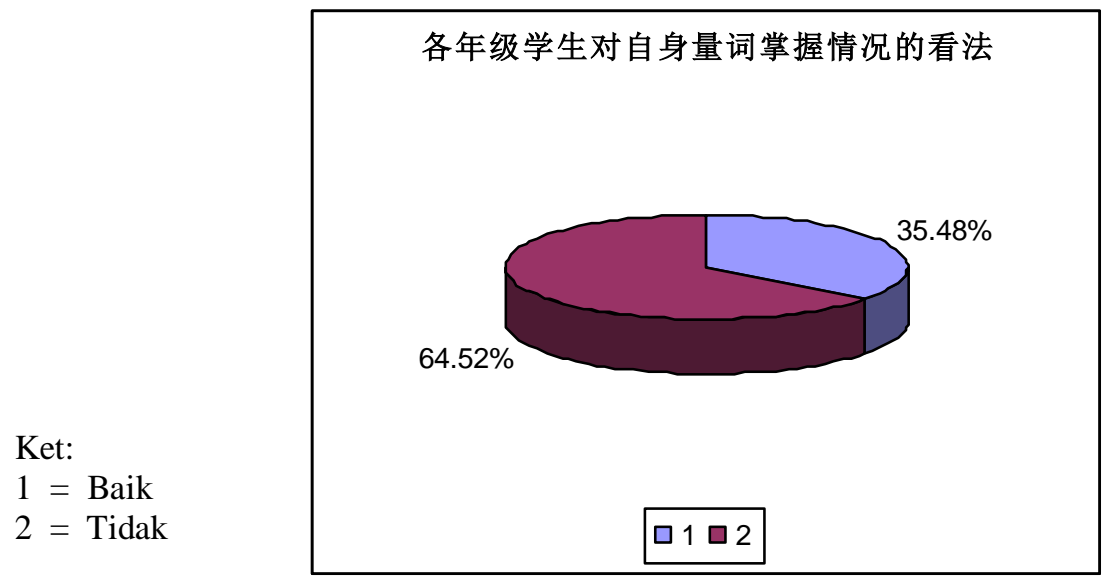

Gambar 3 Pandangan Seluruh Responden terhadap Penguasaan Dirinya Akan Kata Bantu Bilangan Bahasa Mandarin

Dari Gambar 3 diketahui bahwa dari seluruh mahasiswa setiap tingkat ada 64.52\% mahasiswa merasa penguasaan dirinya akan cara penggunaan kata bantu bilangan bahasa Mandarin tidak baik dan ada $35.48 \%$ mahasiswa merasa dirinya sudah menguasai cara penggunaan kata bantu bilangan bahasa Mandarin dengan baik. Hal itu berarti lebih dari setengah jumlah responden mahasiswa merasa penguasaan dirinya akan cara penggunaan kata bantu bilangan bahasa Mandarin tidak baik. Peneliti menyarankan mahasiswa yang sudah menyadari dirinya kurang menguasai cara penggunaan kata bantu bilangan bahasa Mandarin harus memperdalam penguasaan akan kata bantu bilangan bahasa Mandarin, misalnya dengan banyak membaca materi yang ada hubungannya dengan kata bantu bilangan bahasa Mandarin dan meningkatkan kesadaran akan pentingnya mempelajari kata bantu bilangan bahasa Mandarin. 
- Alasan seluruh responden mengapa penguasaan kata bantu bilangan bahasa Mandarin tidak baik

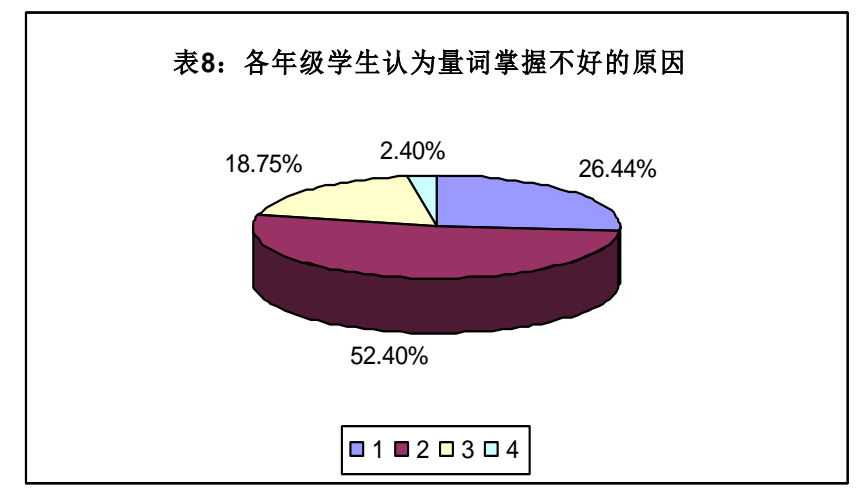

Gambar 4 Alasan Seluruh Responden Mengapa Penguasaan Kata Bantu Bilangan Bahasa Mandarin Tidak Baik

1. Kurang diajarkan dalam materi perkuliahan

2. Kata bilangan bahasa Mandarin jumlahnya banyak

3. Perasaan malas dari diri sendiri

4. Kata bantu bilangan bahasa Mandarin tidak penting untuk dipelajari

Dari Gambar 4 diketahui bahwa dari seluruh responden mahasiswa di setiap tingkatnya ada $52.40 \%$ merasa penyebab mereka kurang menguasai kata bantu bilangan bahasa Mandarin adalah kata bilangan bahasa Mandarin jumlahnya sangat banyak, ada $26.44 \%$ responden merasa kata bantu bilangan bahasa Mandarin kurang diajarkan dalam materi perkuliahan, ada $18.75 \%$ responden merasa perasaan malas dari diri sendiri, dan ada $2.40 \%$ merasa kata bantu bilangan bahasa Mandarin tidak penting untuk dipelajari. Kebanyakan mahasiswa merasa kata bantu bilangan bahasa Mandarin yang sangat banyak menjadi penyebab penguasaan dirinya akan kata bantu bilangan bahasa Mandarin menjadi kurang baik, mendekati setengah responden merasa penyebabnya adalah mereka kurang menyadari pentingnya mempelajari kata bantu bilangan bahasa Mandarin karena dibandingkan dengan bahasa Indonesia, cara penggunaan kata bantu bilangan bahasa Mandarin lebih luas. Hal tersebut merupakan alasan mengapa mahasiswa kurang memahami pentingnya menguasai kata bantu bilangan bahasa Mandarin.

- Menurut Anda, bagaimana cara meningkatkan penguasaan akan kata bantu bilangan bahasa Mandarin?

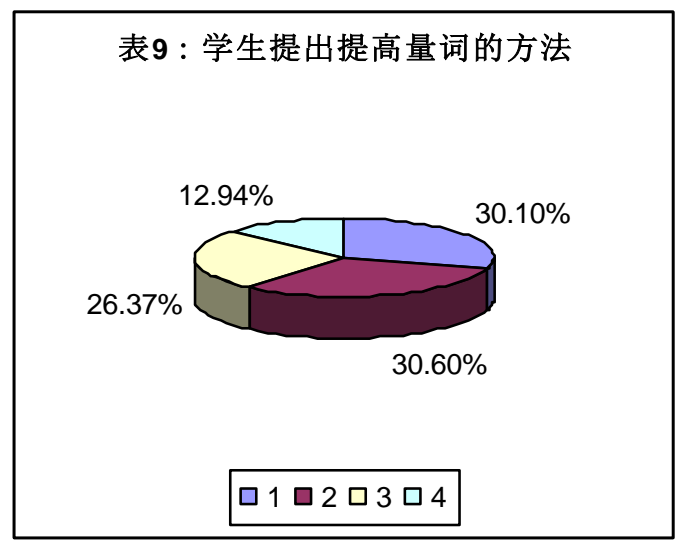

Gambar 5 Pandangan Seluruh Responden terhadap Cara Meningkatkan Penguasaan Akan Kata Bantu Bilangan Bahasa Mandarin 
Ket:

1. Sering membaca buku Mandarin

2. Sering mengerjakan latihan

3. Sering mempraktikkannya dalam percakapan sehari-hari

4. Memperhatikan pelajaran yang diterangkan

Dari Gambar 5 diketahui ada 30.60\% responden berpendapat untuk meningkatkan penguasaan akan kata bantu bilangan harus banyak mengerjakan latihan, ada $30.10 \%$ responden berpendapat dengan sering membaca buku Mandarin, ada $26.37 \%$ responden berpendapat dengan sering mempraktikkannya dalam percakapan sehari-hari, dan ada $12.94 \%$ responden berpendapat dengan memperhatikan pelajaran yang diterangkan. Hal itu menunjukkan untuk meningkatkan penguasaan akan kata bantu bilangan bahasa Mandarin mahasiswa harus memperluas pembendaharaan kata serta meningkatkan kesadaran akan pentingnya mempelajari kata bantu bilangan bahasa Mandarin.

- Menurut Anda, apa saja yang menjadi hambatan bagi mahasiswa dalam mempelajari kata bantu bilangan?

Gambar 6 Hambatan Mahasiswa dalam Mempelajari

Kata Bantu Bilangan Bahasa Mandarin

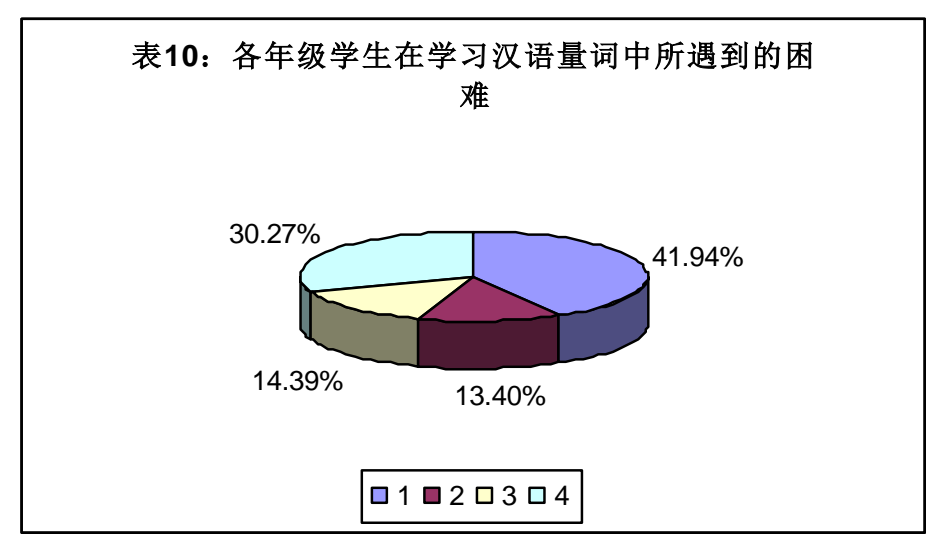

Ket:

1. Kata bantu bilangan bahasa Mandarin jumlahnya banyak

2. Perasaan malas diri sendiri untuk mempelajarinya

3. Kata bantu bilangan bahasa Mandarin jarang dibahas dalam perkuliahan

4. Kurang latihan

Dari Gambar 6 diketahui ada 41.94\% responden berpendapat hambatan dalam mempelajari kata bantu bilangan bahasa Mandarin adalah kata bantu bilangan bahasa Mandarin jumlahnya banyak, ada $30.27 \%$ responden berpendapat karena kurang latihan, ada $14.39 \%$ responden berpendapat karena kata bantu bilangan bahasa Mandarin jarang dibahas dalam perkuliahan, dan ada $13.39 \%$ responden berpendapat karena perasaan malas diri sendiri untuk mempelajarinya. Hal itu berarti kata bantu bilangan bahasa Mandarin yang jumlahnya banyak adalah hambatan yang dialami mahasiswa dalam mempelajari kata bantu bilangan bahasa Mandarin, sikap belajar mahasiswa juga berdampak pada penguasaan akan kata bantu bilangan bahasa Mandarin. 


\section{PENUTUP}

Dalam meneliti artikel ini digunakan tes, penyebaran kuesioner, dan wawancara. Melalu kuis diketahui penguasaan mahasiswa tingkat 2-4 akan kata bantu bilangan bahasa Mandarin tidak baik. Lama waktu belajar di Universitas Bina Nusantara tidak berdampak pada penguasaan akan kata bantu bilangan bahasa Mandarin. Persentase kesalahan mahasiswa terhadap kata bantu bilangan bahasa Mandarin yang jarang muncul lebih tinggi sedangkan terhadap kata bantu bilangan bahasa Mandarin yang sering muncul persentase kesalahan lebih kecil.

Melalui penyebaran kuesioner diketahui kebanyakan mahasiswa merasa kata bantu bilangan bahasa Mandarin sulit dipelajari karena kata bantu bilangan bahasa Mandarin jumlahnya sangat banyak, tata cara penggunaannya lebih luas, membutuhkan ketelitian untuk menguasainya. Kebanyakan mahasiswa berpendapat bahwa penguasaan dirinya akan kata bantu bilangan bahasa Mandarin tidak baik. Penyebabnya adalah kata bantu bilangan jarang dibahas dalam mata perkuliahan, perasaan malas dirinya untuk mempelajarinya, mahasiswa merasa kata bantu bilangan tidak penting untuk dipelajari. Mahasiswa merasa kesulitan dalam mempelajari kata bantu bilangan bahasa Mandarin adalah kata bantu bilangan bahasa Mandarin jumlahnya banyak, perasaan malas dirinya untuk mempelajariya, dan jarang mengerjakan latihan. Hal tersebut menunjukkan kesadaran mahasiswa akan pentingnya menguasai kata bantu bilangan bahasa Mandarin masih kurang. Mahasiswa berpendapat untuk meningkatkan penguasaan akan kata bantu bilangan bahasa Mandarin harus banyak membaca buku Mandarin, sering mengerjakan latihan, mempraktikkannya dalam kehidupan sehari-hari, memperhatikan pelajaran yang diterangkan dosen saat di kelas. Disarankan mahasiswa harus meningkatkan kesadaran akan pentingnya mempelajari kata bantu bilangan bahasa Mandarin, meningkatkan pembelajaran kata bantu bilangan bahasa Mandarin, banyak membaca materi yang ada hubungannya dengan kata bantu bilangan bahasa Mandarin, dan mengerjakan latihan.

\section{DAFTAR PUSTAKA}

《对外汉语教学使用语法》, 卢福波

《初级汉语课本》, 原北京语言学院来华留学生三系

《外国人使用汉语语法》, 程美珍, Sinolingua Beijing,1988年

《汉语量词》, 焦凡教授, 华语教学出版社

《简明汉语语法学习手册》, 周晓星, 北京大学出版社, 2002年

《现代汉语上册》, 黄伯荣, 高等教育出版社, 2002年7月出版

《汉语教程第一册上》, 杨寄洲, 北京语言大学出版社, 2003年

《汉语教程第一册下》, 杨寄洲, 北京语言大学出版社, 2003年

《汉语教程第二册上》, 杨寄洲, 北京语言大学出版社, 2003 年

《汉语教程第二册下》, 杨寄洲, 北京语言大学出版社, 2003年 
Keraf, G.1999. Tata bahasa baku bahasa Indonesia. Jakarta: Departemen Pendidikan dan Kebudayaan Republik Indonesia.

Mularsih, H. Juli 2006.Pembelajaran bahasa kedua. Mimbar Bahasa.2.47-57.

Purwanto, E. A. dan Sulistyastuti, D. R. 2007. Metode penelitian kuantitatif untuk administrasi publik dan masalah-masalah sosial. Yogyakarta: Gaya Media

Safioedin, A.1973. Tata bahasa Indonesia.Bandung: Peladjar.

Suparto. 2003. Tata bahasa Mandarin itu mudah. Penerbit: Puspa Suara.

Wolters, J.B. 1954. Tata bahasa Indonesia. Djakarta: Groningen. 